\title{
PENGARUH CORPORATE GOVERNANCE PADA KEPATUHAN PENGUNGKAPAN TRANSAKSI BERELASI BERDASARKAN PERNYATAAN STANDAR AKUNTANSI KEUANGAN (PSAK) NO. 7 TAHUN 2015.
}

\author{
Ardhana Reswari Hasna Pratista \\ Prodi Akuntansi, Universitas Negeri Yogyakarta \\ ardhanareswari1701@gmail.com
}

\begin{abstract}
Abstrak : Pengaruh Corporate Governance Pada Kepatuhan Pengungkapan Transaksi Berelasi Berdasarkan Pernyataan Standar Akuntansi Keuangan (Psak) No. 7 Tahun 2015. Penelitian ini bertujuan untuk mengetahui pengaruh corporate governance terdahap kepatuhan pengungkapan transaksi pihak berelasi. Variabel independen dalam penelitian ini adalah komite audit, kepemilikan institusional, kepemilikan manajemen, dan komisaris independen. Variabel dependen dalam penelitian ini adalah kepatuhan pengungkapan transaksi pihak berelasi. Jenis penelitian ini merupakan penelitian kuantitatif dengan menggunakan data sekunder berupa laporan keuangan tahunan dari perusahaan sektor utama selama tahun 2015 sampai 2016 yang didapat dari Bursa Efek Indonesia. Teknik pengambilan sampel yang digunakan adalah purposive sampling dan sebanyak 21 perusahaan memenuhi kriteria kelengkapan data akhirnya 42 laporan keuangan tahunan yang dipakai dalam penelitian ini. Metode statistika yang digunakan adalah regresi panel. Dari analisis yang dilakukan komite audit, kepemilikan manajemen, dan komisaris independen berpengaruh secara positif signifikan terhadap pengungkapan transaksi pihak berelasi, sementara kepemilikan institusi tidak berpengaruh secara positif terhadap pengungkapan transaksi pihak berelasi.
\end{abstract}

Kata kunci: corporate governance, pengungkapan, transaksi pihak berelasi

Abstract: The Influence Of Corporate Governance To Related Party Transaction Disclosure Based On Statement Of Financial Accounting Standard (Psak) Number 7 Year Of 2015. The purpose of this study is to examine the effect of corporate governance to the related parties transactions disclosure. The independent variables in this study are audit committee, institutions ownership, management ownership, and independent commissioner. The dependent variable in this research is the related parties transaction disclosure. This type of research is quantitative research using secondary data of annual financial statements from major sector companies during 2015 to 2016 obtained from Indonesia Stock Exchange. The sampling technique that used in this research is purposive sampling and that are 21 companies that meet the criteria as the sample and finally 42 annual reports used in this analysis. The statistical method used in this study is panel regression. The analysis showed that audit committee, ownership of management, and independent commissioner have a significant influence to related party transactions disclosure, but Institusional ownership has no influence to related party transactions disclosure.

Keywords: corporate governance, disclosure, related party transaction

\section{PENDAHULUAN}

Terdapat 2 bentuk umum struktur kepemilikan, yaitu struktur kepemilikan tersebar dan struktur kepemilikan terkonsentrasi. Perbedaan dari kedua struktur tersebut adalah pada proses pengambilan keputusan. Pada struktur kepemilikan terkonsentrasi, pemegang 


\section{JURNAL NOMINAL / VOLUME VIII NOMOR 1 / TAHUN 2019}

saham memilih dan melantik manajer yang bekerja untuk kepentingan pemegang saham pengendali sedangkan pemegang saham lain hanya memiliki sedikit kewenangan dalam pemilihan manajer.

Perusahaan di Indonesia pada umumnya memiliki grup perusahaan yang berhubungan karena kepemilikan saham ataupun karena keterkaitan kepentingan baik antara perusahaan induk (parent company) dan anaknya ataupun antar cabang perusahaan (sister company) atau yang disebut pula sebagai pihak-pihak yang mempunyai hubungan istimewa dengan perusahaan (related parties) (Indah Rini: 2014).

Sari (2014) mengungkapkan struktur kepemilikan keluarga dan grup pada perusahaan di Indonesia memicu terjadinya transaksi pihak berelasi. Pemegang saham pengendali atau terkonsentrasi melakukan transaksi pihak berelasi lebih tinggi dibanding perusahaan yang tidak memiliki pemegang saham pengendali atau tersebar. Pada tahun 2008, perusahaan yang memiliki struktur kepemilikan terkonsentrasi mempunyai rata-rata penjualan pada pihak berelasi sebesar 55\% dari nilai aset, nilai tersebut lebih tinggi dibanding perusahaan yang tersebar, yaitu sebesar $10 \%$ dari nilai aset. Hasil tersebut konsisten untuk tahun 2009 dan 2010, bahwa rata-rata penjualan kepada pihak berelasi lebih tinggi pada perusahaan dengan kepemilikan terkonsentrasi. Dalam beberapa kondisi transaksi pihak berelasi dapat membuka peluang timbulnya tujuan oportunis yakni penyalahgunaan transaksi pihak berelasi yang akan merugikan pemegang saham minoritas dan hanya menguntungkan pemegang saham pengendali.

Menurut Heni Werdhi (2015) transaksi pihak berelasi harus diungkapkan dalam laporan keuangan, karena pengungkapan tersebut merupakan kunci bagi pengguna laporan keuangan untuk membuat keputusan dan memahami dampak transaksi pada perusahaan, termasuk adanya transfer kekayaan. Hal tersebut sesuai dengan PSAK No. 7 Tahun 2015, menyatakan bahwa tujuan dari pernyataan ini adalah untuk memastikan bahwa laporan keuangan entitas berisi pengungkapan yang diperlukan untuk dijadikan perhatian terhadap kemungkinan bahwa keputusan perusahaan telah dipengaruhi oleh keberadaan pihak-pihak berelasi.

Pengungkapan transaksi pihak berelasi menurut Arshad (2009) adalah untuk menyediakan informasi mengenai praktik transaksi pihak berelasi dan hubungan dengan investor luar dan stakeholder lainya dan sebagai bagian dari gerakan corporate governance dan konvergensi dari International Financial Reporting Standar (IFRS). 


\section{JURNAL NOMINAL / VOLUME VIII NOMOR 1 / TAHUN 2019}

Menurut penelitian yang dilakukan oleh Prawinandi, dkk (2012) mekanisme corporate governance juga mempengaruhi tingkat kepatuhan pengungkapan wajib. Corporate governance merupakan mekanisme pengendalian untuk mengatur dan mengelola perusahaan dengan maksud untuk meningkatkan kemakmuran dan akuntabilitas perusahaan, yang tujuan akhirnya untuk mewujudkan shareholders value. Corporate governance merupakan suatu sistem yang mengatur dan mengendalikan perusahaan yang diharapkan dapat memberikan dan meningkatkan nilai perusahaan kepada para pemegang saham.

\section{Selain itu Good Corporate} Governance (GCG) merupakan komponen penting yang harus diperhatikan perusahaan. Amerika Serikat yang harus melakukan restrukturisasi corporate governance akibat market crash pada tahun 1929. Kebutuhan corporate governance timbul berkaitan dengan agency theory dikarenakan perusahaan menginginkan suatu proses pengawasan terhadap keputusan yang dilakukan manajemen agar tidak terjadi penyimpangan. Implementasi dari corporate governance diharapkan bermanfaat untuk menambah dan memaksimalkan nilai perusahaan. Menurut Saputra (2013), corporate governance diharapkan mampu mengusahakan keseimbangan antara berbagai kepentingan yang dapat memberikan keuntungan bagi perusahaan secara menyeluruh, dan juga akan bermanfaat untuk mempermudah memperoleh modal, cost of capital jadi lebih rendah.

$$
\text { Menurut Chintya (2014) krisis }
$$
ekonomi dan moneter pada tahun 19971999 yang ada di Indonesia berkembang menjadi krisis multidimensi yang berkepanjangan, krisis tersebut antara lain terjadi karena banyak perusahaan yang belum menerapkan Good Corporate Governance secara konsisten, khususnya belum diterapkannya etika bisnis. Corporate covernane mendorong perusahaan melakukan operasinya secara etis karena dianggap dapat menyeimbangkan berbagai kepentingan stakeholder. Adanya penerapaan Good Corporate Governanve ini akan membawa pengaruh terhadap kinerja perusahaan. Selain itu, kerugian yang ditimbulkan dari transaksi pihak berelasi yang disalahgunakan sangat tinggi, sehingga pemantauan dan penertiban transaksi pihak berelasi adalah menjadi prioritas utama reformasi corporate governance $\mathrm{di}$ Indonesia.

Komite audit adalah salah satu unsur corporate governance. Menurut Sutedi (2012:161) komite audit harus dapat memastikan bahwa perusahaan telah melaksanakan dan mematuhi semua peraturan hukum, serta memastikan 


\section{JURNAL NOMINAL / VOLUME VIII NOMOR 1 / TAHUN 2019}

perusahaan telah menjalankan usahanya secara etis dan bermoral. Unsur Corporate governance lainnya adalah struktur kepemilikan. Menurut Barako (2007) struktur kepemilikan mempengaruhi pengungkapan yang dilakukan perusahaan. Penelitian yang dilakukan oleh Dwi, dkk (2012) juga menyatakan bahwa salah satu faktor yang mempengaruhi tingkat kepatuhan adalah struktur kepemilikan yang ada di sebuah perusahaan.pihak asing, maupun orang dalam perusahaan tersebut (manajemen). Pada penelitian ini mekanisme struktur kepemilikan adalah kepemilikan institusional dan kepemilikan manajemen. Kepemilikan institusional adalah proporsi kepemilikan saham pada akhir tahun yang dimiliki oleh lembaga, seperti asuransi, bank atau institusi lain (Beiner et al, 2003). Kepemilikan institusional, umumnya dapat bertindak sebagai pihak yang memonitor perusahaan. Mekanisme struktur kepemilikan selanjutnya adalah kepemilikan manajemen, merupakan kepemilikan saham oleh manajemen perusahaan yang diukur dengan persentase jumlah saham yang dimiliki oleh manajemen. Kepemilikan oleh manajemen dipandang dapat menyelaraskan potensi perbedaan kepentingan antara pemegang saham luar dengan manajemen (Jensen and Meckling, 1976). Dengan adanya kepemilikan manajerial maka manajemen akan bertindak layaknya pemegang saham dan akan melakukan praktik pengelolaan perusahaan yang akan meningkatkan nilai pemegang saham. Unsur corporate governance lainnya yakni komisaris independen. Adanya komisaris independen diharapkan mampu meningkatkan peran dewan komisaris sehingga tercipta good corporate governance di dalam perusahaan. Komisaris independen bertugas untuk mengawasi direksi perusahaan tanpa ada tekanan dari pihak manapun, sehingga pekerjaan yang dilakukannya murni tanpa ada campur tangan dengan pihak manapun (Dananjaya, 2014). Penelitian ini bermaksud untuk menguji bagaimana pengaruh Corporate Governance yang akan dijabarkan dalam 4 unsur yaitu komite audit, kepemilikan institusional, kepemilikan manajerial, dan komisaris independen berkaitan dengan kepatuhan pengungkapan transaksi pihak berelasi, maka penulis memilih judul "Pengaruh Corporate Governance pada Tingkat Kepatuhan Pengungkapan Transaksi Berelasi Berdasarkan PSAK No 7 tentang Pengungkapan Pihak-Pihak Berelasi”.

\section{METODE PENELITIAN}

\section{Jenis Penelitian}

Penelitian ini merupakan penelitian kuantitatif. 


\section{JURNAL NOMINAL / VOLUME VIII NOMOR 1 / TAHUN 2019}

\section{Waktu dan Tempat Penelitian}

Waktu penelitian dilaksanakan pada bulan Desember 2017 sampai dengan Maret 2018. Tempat penelitian dilaksanakan di Bursa Efek Indonesia. Populasi dan

\section{Sampel Penelitian}

Populasi yang digunakan dalam penelitian ini adalah perusahaan non keuangan pada sektor utama yang terdaftar di Bursa Efek Indonesia pada tahun 20152016.

Karakteristik sampel pada penelitian ini adalah Mahasiswa Akuntansi Universitas Negeri Yogyakarta yang sudah menempuh mata kuliah Auditing 1 dan 2 dengan jumlah 118 Sampel.

Karakteristik responden yang dapat menjadi sampel dalam penelitian ini adalah:

1. Perusahaan non keuangan yang listed di BEI selama tahun 2015-2016.

2. Perusahaan termasuk dalam perusahaan sektor utama yakni perusahaan sektor pertambangan dan sektor pertanian karena dinilai memiliki kemungkinan lebih tinggi terjadinya transaksi berelasi dengan tujuan oportunis.

3. Perusahaan telah mempublikasikan laporan keuangan perusahaan yang telah di audit.

4. Merupakan perusahaan non BUMN, karena terdapat perbedaan peraturan pengungkapan antara perusahaan BUMN dan non BUMN.
5. Memiliki informasi tentang pengungkapan transaksi pihak berelasi.

Sesuai dengan kriteria yang telah ditetapkan maka terdapat 42 sampel perusahaan dalam 2 tahun yaitu tahun 2015 dan 2016.

\section{Teknik Pengumpulan Data}

Penelitian ini menggunakan data kuantitatif yang berupa data sekunder. Data sekunder yang digunakan diperoleh dari laporan keuangan yang terdapat di Bursa Efek Indonesia melalui website resmi Bursa Efek Indonesia (www.idx.co.id).

\section{Teknik Analisis Data}

Dalam penelitian ini teknik yang digunakan adalah regresi panel dengan variabel dependen Kepatuhan Pengungkapan Transaksi Pihak Berelasi (Y) dan variabel independen Komite Audit (X1), Kepemilikan Institusional (X2), Kepemilikan Manajemen (X3), Komisaris Independen (X4). Model persamaan regresi yang digunakan adalah dengan model analisis regresi panel, Dalam teori ekonometri, data panel merupakan gabungan antara data cross-section (silang) dan data time-series (deret waktu). Data cross-section dalam penelitian ini merupakan data yang diperoleh dari 21 perusahaan yang terdaftar dalam BEI pada sektor utama. Sedangkan, data time-series dalam penelitian ini merupakan data yang diambil dari tahun 2015-2016. 
JURNAL NOMINAL / VOLUME VIII NOMOR 1 / TAHUN 2019

HASIL PENELITIAN DAN PEMBAHASAN

\begin{tabular}{|c|c|c|c|c|}
\hline $\mathbf{Y}$ & Coef. & $\begin{array}{l}\text { Std. } \\
\text { Err. }\end{array}$ & $\mathbf{T}$ & $\begin{array}{c}\mathbf{P} \\
\text { Value }\end{array}$ \\
\hline $\mathrm{X1}$ & 0,208 & 0,069 & 3,00 & 0.003 \\
\hline $\mathrm{X} 2$ & $-0,118$ & 0,132 & $-0,90$ & 0.370 \\
\hline $\mathbf{X 3}$ & 0,044 & 0,014 & 3,05 & 0.002 \\
\hline X4 & 0,390 & 0,127 & 3,07 & 0.002 \\
\hline cons & $-0,278$ & 0,147 & $-1,89$ & 0.059 \\
\hline
\end{tabular}

Tabel 1. Hasil Uji t (Sumber: Data Diolah 2018)

\section{Uji Hipotesis 1}

Hipotesis pertama penelitian ini adalah Komite Audit berpengaruh terhadap Kepatuhan Pengungkapan Transaksi Pihak Berelasi. Dari hasil pengujian, diperoleh nilai koefisien sebesar 0,208 dengan probabilitas sebesar $0.003(\mathrm{p}<0,050)$ yang berarti ada pengaruh variabel komite audit (X1) terhadap pengungkapan transaksi pihak berelasi berdasarkan PSAK No 7 tahun 2015 (Y). Hal tersebut menunjukkan bahwa semakin tinggi jumlah anggota komite audit, akan meningkatkan kepatuhan pengungkapan transaksi pihak berelasi berdasarkan PSAK No 7 tahun 2015. Jadi, dapat disimpulkan bahwa hipotesis pertama yang menyatakan ada pengaruh komite audit (X1) terhadap kepatuhan pengungkapan transaksi pihak berelasi berdasarkan PSAK No 7 tahun 2015 (Y) diterima.

\section{Uji Hipotesis 2}

Hipotesis kedua penelitian ini adalah Kepemilikan Institusional berpengaruh terhadap Kepatuhan Pengungkapan Transaksi Pihak Berelasi. Dari hasil pengujian, diperoleh nilai koefisien sebesar $-0,118$ dengan probabilitas sebesar $0.370(\mathrm{p}>0,050)$ yang berarti pengaruh variabel kepemilikan institusional (X2) terhadap pengungkapan transaksi pihak berelasi berdasarkan PSAK No 7 tahun 2015 (Y) adalah negatif. Namun, pengaruh yang diberikan tidaklah signifikan disebabkan probabilitas value lebih besar dari pada 0,050. Jadi, dapat disimpulkan bahwa hipotesis kedua yang menyatakan ada pengaruh kepemilikan institusional (X2) terhadap kepatuhan pengungkapan transaksi pihak berelasi berdasarkan PSAK No 7 tahun 2015 (Y) ditolak.

\section{Uji Hipotesis 3}

Hipotesis ketiga penelitian ini adalah Kepemilikan Manajemen berpengaruh terhadap Kepatuhan Pengungkapan Transaksi Pihak Berelasi. Dari hasil pengujian, diperoleh nilai koefisien sebesar 0,044 dengan probabilitas sebesar $0.002(\mathrm{p}<0,050)$ yang berarti ada pengaruh variabel kepemilikan manajemen (X3) terhadap pengungkapan transaksi pihak berelasi berdasarkan PSAK No 7 tahun 2015 (Y). Hal tersebut menunjukkan bahwa semakin besar persentase 


\section{JURNAL NOMINAL / VOLUME VIII NOMOR 1 / TAHUN 2019}

kepemilikan yang dimiliki oleh manajemen, akan meningkatkan pengungkapan transaksi pihak berelasi berdasarkan PSAK No 7 tahun 2015. Jadi, dapat disimpulkan bahwa hipotesis ketiga yang menyatakan ada pengaruh kepemilikan manajemen (X3) terhadap pengungkapan transaksi pihak berelasi berdasarkan PSAK No 7 tahun 2015 (Y) diterima.

\section{Uji Hipotesis 4}

Hipotesis keempat penelitian ini adalah Komisaris Independen berpengaruh terhadap Kepatuhan Pengungkapan Transaksi Pihak Berelasi. Dari hasil pengujian, diperoleh nilai koefisien sebesar 0,390 dengan probabilitas sebesar 0.002 $(\mathrm{p}<0,050)$ yang berarti ada pengaruh variabel komisaris independen (X4) terhadap pengungkapan transaksi pihak berelasi berdasarkan PSAK No 7 tahun 2015 (Y). Hal tersebut menunjukkan bahwa banyak jumlah anggota komisaris indepenen yang beada dalam perusahaan, akan meningkatkan pengungkapan transaksi pihak berelasi berdasarkan PSAK No 7 tahun 2015. Jadi, dapat disimpulkan bahwa hipotesis keempat yang menyatakan ada pengaruh komisaris independen (X4) terhadap pengungkapan transaksi pihak berelasi berdasarkan PSAK No 7 tahun 2015 (Y) diterima.

\section{Uji Hipotesis 5}

Hipotesis kelima penelitian ini adalah komite audit, kepemilikan institusional, kepemilikan manajemen, dan komisaris independen berpengaruh terhadap Kepatuhan Pengungkapan Transaksi Pihak Berelasi.

\begin{tabular}{ll}
\hline F Hitung & $\mathbf{6 5 , 0 2 0}$ \\
\hline Probabilitas & 0,000
\end{tabular}

Tabel 2. Hasil Uji F (Sumber: Data Diolah)

Dari perhitungan yang tertera, karena probabilitas sebesar 0,000 adalah lebih kecil daripada 0,050 maka variabel independen secara bersama-sama berpengaruh terhadap y. Jadi, dapat disimpulkan bahwa hipotesis kelima yang menyatakan ada pengaruh komite audit (X1), kepemilikan institusional (X2), kepemilikan manajemen (X3), dan komisaris independen (X4) terhadap pengungkapan transaksi pihak berelasi berdasarkan PSAK No 7 tahun 2015 (Y) diterima.

$\mathbf{R}^{2} \quad 0,875$

Adjusted R $\mathbf{R}^{2} \quad 0,862$

Tabel 3. Hasil Uji R2 (Sumber: Data Diolah)

Dari data yang telah diolah didapatkan nilai $\mathrm{R}^{2}$ 0,875 dan Adjusted $\mathrm{R}^{2}$ adalah sebesar sebesar 0,865. Artinya bahwa variabel Komite Audit, Kepemilikan Institusional, Kepemilikan Manajemen, 


\section{JURNAL NOMINAL / VOLUME VIII NOMOR 1 / TAHUN 2019}

dan Komisaris Indepeden secara bersamasama memiliki sumbangan pengaruh terhadap Y sebesar 0,875 atau $87 \%$ dan sisa dipengaruhi faktor lain yang tidak diteliti.

\section{SIMPULAN DAN SARAN}

\section{Simpulan}

Berdasarkan hasil penelitian pengaruh Corporate Governance terhadap Kepatuhan Pengungkapan Transaksi Pihak Berelasi Berdasarkan Pernyataan Standar Akuntansi Keuangan (PSAK) no. 7 tahun 2015 pada perusahaan industri sektor utama yang terdaftar di Bursa Efek Indonesia periode 2015-2016, dengan menggunakan teknik analisis regresi panel/PLS menyimpulkan bahwa:

1) Komite audit berpengaruh secara positif terhadap kepatuhan pengungkapan transaksi pihak berelasi berdasarkan pernyataan standar akuntansi keuangan (PSAK) no. 7 tahun 2015 pada perusahaan industri sektor utama. Dari hasil pengujian, diperoleh nilai koefisien sebesar 0,208 dengan probabilitas sebesar $0.003(\mathrm{p}<0,05)$ yang berarti ada pengaruh positif signifikan variabel komite audit terhadap pengungkapan transaksi pihak berelasi berdasarkan PSAK No 7 tahun 2015.

2) Hipotesis kedua yang menyatakan kepemilikan institusional berpengaruh secara positif terhadap kepatuhan pengungkapan transaksi pihak berelasi berdasarkan pernyataan standar akuntansi keuangan (PSAK) no. 7 tahun 2015 pada perusahaan industri sektor utama ditolak. Dari hasil pengujian, diperoleh nilai koefisien sebesar $-0,118$ dengan probabilitas sebesar 0.370 ( $p>0,05)$ yang berarti tidak ada pengaruh variabel kepemilikan terhadap pengungkapan transaksi pihak berelasi berdasarkan PSAK No 7 tahun 2015.

3) Kepemilikan manajemen berpengaruh secara positif terhadap kepatuhan pengungkapan transaksi pihak berelasi berdasarkan pernyataan standar akuntansi keuangan (PSAK) no. 7 tahun 2015 pada perusahaan industri sektor utama. Dari hasil pengujian, diperoleh nilai koefisien sebesar 0,044 dengan probabilitas sebesar $0.002(\mathrm{p}<0,05)$ yang berarti ada pengaruh variabel kepemilikan manajemen terhadap pengungkapan transaksi pihak berelasi berdasarkan PSAK No 7 tahun 2015.

4) Komisaris independen berpengaruh terhadap kepatuhan pengungkapan transaksi pihak berelasi berdasarkan pernyataan standar akuntansi keuangan (PSAK) no. 7 tahun 2015 


\section{JURNAL NOMINAL / VOLUME VIII NOMOR 1 / TAHUN 2019}

pada perusahaan industri sektor utama. Dari hasil pengujian, diperoleh nilai koefisien sebesar 0,390 dengan probabilitas sebesar $0.002(\mathrm{p}<0,05)$ yang berarti ada pengaruh variabel komisaris independen terhadap pengungkapan transaksi pihak berelasi berdasarkan PSAK No 7 tahun 2015.

5) Komite audit, kepemilikan institusional, kepemilikan manajemen, dan komisaris independen berpengaruh terhadap pengungkapan transaksi pihak berelasi berdasarkan PSAK No 7 tahun 2015 pada perusahaan industri sektor utama. Dari perhitungan yang tertera, karena probabilitas sebesar 0,0000 adalah lebih kecil daripada 0,05 maka variabel independen secara bersama-sama berpengaruh terhadap dependen.

\section{Saran}

Saran bagi pemerintah:

1) Pemerintah melalui OJK dapat terus mendorong tingkat pengungkapan RPT untuk lebih baik lagi karena dapat mendukung transparansi laporan keuangan.

2) Pemerintah melalui OJK dapat meningkatkan kualitas praktik corporate governance perusahaan agar hak dan kesetaraan pemegang saham dapat diterima dengan adil antara pemegang saham mayoritas dan pemegang saham minoritas.

Saran bagi manajemen:

1) Keberhasilan dalam perwujudan prinsip corporate governance memerlukan kerjasama yang baik antar pihak manajemen dan stakeholder. Oleh karena itu, manajemen perlu melakukan kerjasama dan koordinasi yang lebih baik guna memenuhi prinsip corporate governance.

Saran bagi investor:

1) Investor harus lebih berhati-hati dalam memilih perusahaan yang terkonsentrasi kepemilikannya karena dapat mendorong penyalahgunaan transaksi pihak berelasi.

\section{DAFTAR PUSTAKA}

Alvionita, I. \& Taqwa, S. (2015). Pengaruh Struktur Kepemilikan dan Mekanisme Corporate Governance terhadap Tingkat Kepatuhan Mandatory Disclosure. Seminar Nasional Ekonomi Manajemen dan Akuntansi (SNEMA) Fakultas Ekonomi Universitas Negeri Padang.

Azwari, Peny Dan Raden Fatah. 2016. Masalah Keagenan Pada Struktur Kepemilikan

Perusahaan 
Keluarga Di Indonesia. Jurnal Publikasi: Universitas Islam Negeri Jakarta.

Bukhori, Iqbal Dan Raharja. 2012. Pengaruh Good Corporate Governance Dan Ukuran Perusahaan Terhadap Kinerja Perusahaan. Jurnal Publikasi: Diponegoro Journal Of Accounting

Desianti Dan Udi Pramiudi. 2016. Analisis Penerapan Psak 7 Dalam Pengungkapan Transaksi PihakPihak Berelasi Terkait Entitas Asosiasi Pada Perusahaan Go Public. Naskah Publikasi: Sekolah Tinggi Ilmu Ekonomi Kesatuan Bogor.

FCGI. 2001. Peranan Dewan Komisaris dan Komite Audit dalam Pelaksanaan corporate governance (Tata Kelola Perusahaan). JilidII. FCGI. Edisi ke-2

Ferdinal,Ferry. Pengaruh Kepemilikan Keluarga Terhadap Pengungkapan Sukarela Dengan Efektifitas Dewan Komisars dan Komite Audit Sebagai Variabel Pemoderasi. 2012. Skripsi: Universitas Indonesia

Fitri, Dian. 2012. Analisis Pengaruh Kepemilikan Keluarga Terhadap Tingkat Pengungkapan Sukarela Dengan Efektifitas Dewan Komisaris Sebagai Variabel Moderasi. Naskah Publikasi: Universitas Indonesia
Ghozali, Imam. 2006. Desain Penelitian Kuantitatif dan Kualitatif Akuntansi, Bisnis dan Ilmu Sosial Lainnya. Bandung: Pustaka Setia

Guing, Aaron Dan Aria Farahmita. 2011. Manajemen Laba Dan Tunneling Melalui Transaksi Pihak Istimewa Di Sekitar Penawaran Saham Perdana. Jurnal Publikasi: Simposium Nasional Akuntansi XIV.

Gunawan, Barbara Dan Hendrawati. Peran Struktur Corporate Governance Dalam Tingkat Kepatuhan Pengungkapan Wajib Periode Setelah Konvergensi IFRS. 2015. Jurnal: Berkala Akuntansi Dan Keuangan Indonesia

Hafiz M, Adriani. 2014. Pengaruh Struktur Corporate Governance Terhadap Tingkat Kepatuhan Pengungkapan Wajib Konvergensi Ifrs Pada Laporan Laba Rugi Komprehensif. Jurnal: Universitas Lambung Mangkurat

Handayani, Indah Rini. 2014. Analisis Pengaruh Pembelian Dan Penjualan Kepada Pihak Yang Berelasi Dan Tidak Berelasi Terhadap Laba Bersih Pada Industri Otomotif Dan Komponennya. Jurnal Publikasi: Jurnal Mix, Volume IV No. 1

IAI. 2017. PSAK No 7 Tahun 2015 diakes melalui http://iaiglobal.or.id pada 22 Desember 2017

Jenjang, Fransiska Dan Sri Lestari. 2013. Pengaruh Transaksi Pihak-Pihak Istimewa Terhadap Kinerja Keuangan Perusahaan. Naskah 


\section{JURNAL NOMINAL / VOLUME VIII NOMOR 1 / TAHUN 2019}

Publikasi: Universitas Atma Jaya Yogyakarta.

Komite Nasional Kebijakan Governance (KNKG). 2006. Pedoman Umum Good Corporate Governance di Indonesia. Jakarta

Marliasiwi, Juniar Anes. 2012. Pengaruh Mekanisme Corporate Governance Terhadap Tingkat Kepatuhan Mandatory Disclosure Konvergensi IFRS Di Indonesia Dan Malaysia. Naskah Publikasi Skripsi: Universitas Muhammadiyah Yogyakarta

Praktik Good Corporate Governance Terkait Struktur Kepemilikan Perusahaan Di Indonesia diakses melalui www.kompasiana.com pada 22 Desember 2017

Raharjo, Eko. 2007. Teori Agensi Dan Teori Stewarship Dalam Perspektif Akuntansi (Agency Theory Vs Stewardship Theory In The Accounting Perspective). Jurnal Publikasi: Pena Fokus Ekonomi.

Sari, Ratna Candra \& Sugiharto. 2014. Tunneling dan Corporate Governance. Yogyakarta: Gadjah Mada University Press.

Sekaran, Uma. (2006). Metode Penelitian untuk Bisnis Edisi Keempat. Jakarta: Salemba Empat.

Setyawan, Budi. 2015. Pengaruh Corporate Social Responsibility Dan Good Corporate Governance Terhadap Nilai Perusahaan.
Naskah Publikasi: Universitas Pamulang.

Silviana, Laurent. 2012. Pengaruh Struktur Kepemilikan Dan Transaksi Pihak Yang Berelasi Terhadap Daya Informasi Akuntansi Pada Perusahaan Yang Terdaftar Di BEI. Jurnal Publikasi: Berkala Jurnal Mahasiswa Akuntansi.

Sirait,Immanuel. 2013. Analisis Pengaruh Perusahaan Keluarga dan Corporate Governance Terhadap Risiko Idiosyncratic. Jurnal Publikasi: Universitas Indonesia.

Supriyono, E., Mustaqim, A. B. \& Suhardjono, D. (2014). Pengaruh Corporate Governance Terhadap Tingkat Kepatuhan Mandatory Disclosure Konvergensi IFRS di Indonesia. Simposiun Nasional Akuntansi XVII Mataram, Lombok.

Tobing, Adil dan rekan. 2013. Pengaruh Penerapan Good Corporate Governance terhadap Tingkat Kesehatan dan Daya Saing di Perbankan Indonesia. Jurnal Publikasi: Institut Pertanian Bogor.

Transaksi Hubungan Istimewa Dan Pengaruhnya Terhadap Tarif Pajak Efektif Perusahaan diakses melalui www.researchgate.net pada 22 Desember 2017.

Utama, Cynthia A. 2015. Penentu Besaran Transaksi Pihak Berelasi: Tata Kelola, Tingkat Pengungkapan, Dan Struktur Kepemilikan (Unpublished Undergraduate 
Thesis). Fakultas Ekonomi dan

Bisnis Universitas Indonesia.

Utami, Wulan Dan Djoko Suhardjanto. 2011. Investigasi Dalam Konvergensi Ifrs Di Indonesia: Tingkat Kepatuhan Pengungkapan Wajib Dan Kaitannya Dengan Mekanisme Corporate Governance. Jurnal Publikas: Universitas Sebelas Maret

Werdhi, Heni. 2014. Pengaruh Corporate Governance Dan Karakteristik Perusahaan Terhadap Luas Pengungkapan Transaksi Pihak Berelasi Di Indonesia. 2015. Jurnal Akuntansi Indonesia.

Widarto. 2013. Penelitian Expo Facto. Universitas Negeri Yogyakarta.

Wulan, sari. 2013. Pengaruh Mekanisme Corporate Governance Terhadap Disclosure. Skripsi Publikasi: Universitas Kristen Satya Wacana.

Suhardjanto, Dan Rena Rukmit. 2011. Pengaruh Karakteristik Pemerintah Daerah Terhadap Kepatuhan Pengungkapan Wajib Dalam Laporan Keuangan Pemerintah Daerah (Studi Empiris Pada Kabupaten/Kota Di Indonesia). Jurnal: Universitas Sebelas Maret. 